Article

\title{
Effect of Dried Leaves of Leucaena leucocephala on Rumen Fermentation, Rumen Microbial Population, and Enteric Methane Production in Crossbred Heifers
}

\author{
María Denisse Montoya-Flores ${ }^{1,2, *}$, Isabel Cristina Molina-Botero ${ }^{1,3}$, Jacobo Arango ${ }^{3}$, \\ José Luis Romano-Muñoz ${ }^{2}$, Francisco Javier Solorio-Sánchez ${ }^{1}$ (D), \\ Carlos Fernando Aguilar-Pérez ${ }^{1}$ and Juan Carlos Ku-Vera ${ }^{1}$ \\ 1 Faculty of Veterinary Medicine and Animal Science, Autonomous University of Yucatan, Mérida 97300, \\ Mexico; hyzavell26@gmail.com (I.C.M.-B.); ssolorio@correo.uady.mx (F.J.S.-S.); \\ caperez@correo.uady.mx (C.F.A.-P.); kvera@correo.uady.mx (J.C.K.-V.) \\ 2 National Center for Disciplinary Research in Physiology and Animal Breeding, National Institute for \\ Forestry, Crops, and Livestock Research - Ministry of Agriculture and Rural Development, Ajuchitlán 76280, \\ Mexico; romano.jose@inifap.gob.mx \\ 3 The Alliance of Bioversity International and the International Center for Tropical Agriculture (CIAT), \\ Km 17 Recta Cali-Palmira, A.A. 6713 Cali, Colombia; j.arango@cgiar.org \\ * Correspondence: denis_montoya@yahoo.com.mx
}

Received: 27 December 2019; Accepted: 8 February 2020; Published: 13 February 2020

Simple Summary: The objective of the experiment was to evaluate the effects of dietary supplementation of heifers with increasing levels of dried Leucaena leucocephala leaves (DLL) on nutrient digestibility, fermentation parameters, microbial rumen population, and production of enteric methane $\left(\mathrm{CH}_{4}\right)$. Nutrient digestibility decreased with increasing levels of DLL in the ration. Inclusion of DLL did not have detrimental effects on rumen $\mathrm{pH}$, rumen microbial community, and volatile fatty acids proportions. Enteric $\mathrm{CH}_{4}$ emissions in heifers were reduced with increasing levels of DLL in the ration.

\begin{abstract}
The effects of dietary inclusion of dried Leucaena leucocephala leaves (DLL) on nutrient digestibility, fermentation parameters, microbial rumen population, and production of enteric methane $\left(\mathrm{CH}_{4}\right)$ in crossbred heifers were evaluated. Four heifers were used in a $4 \times 4$ Latin square design consisting of four periods and four levels of inclusion of DLL: $0 \%, 12 \%, 24 \%$, and 36\% of dry matter (DM) intake. Results showed that DM intake (DMI), organic matter intake, and gross energy intake (GEI) were similar $(p>0.05)$ among treatments. Apparent digestibility of organic matter, neutral detergent fiber, and energy decreased with increasing levels of DLL in the ration $(p<0.05)$. In contrast, digestible crude protein $(\mathrm{CP})$ was higher $(p<0.05)$ in treatments with $12 \%$ and $24 \%$ DM of DLL. The inclusion of DLL did not affect $(p>0.05)$ rumen $\mathrm{pH}$ and total volatile fatty acids. Rumen microbial community was not affected $(p>0.05)$ by treatment. There was a linear reduction $(p<0.05)$ in $\mathrm{CH}_{4}$ emissions as the levels of DLL in the ration were increased. Results of this study suggest that an inclusion of $12 \%$ DM of ration as DLL enhances digestible $\mathrm{CP}$ and reduces daily production of enteric $\mathrm{CH}_{4}$ without adversely affecting DMI, rumen microbial population, and fermentation parameters.
\end{abstract}

Keywords: Leucaena leucocephala; methane; digestibility; volatile fatty acids

\section{Introduction}

Methane $\left(\mathrm{CH}_{4}\right)$ is the second most important greenhouse gas (GHG) and it has a potential global warming effect 28 times above that of carbon dioxide $\left(\mathrm{CO}_{2}\right)$ [1]. The livestock sector contributes $14.5 \%$ of global emissions of GHG [2] and $\mathrm{CH}_{4}$ represents $44 \%$ of total anthropogenic emissions [3], where 
$\mathrm{CH}_{4}$ from ruminant enteric fermentation represents $39.1 \%$ of total emissions in the livestock sector [2]. Methane is a byproduct of anaerobic microbial fermentation of feed in the rumen, and energy used for its synthesis is considered as a loss of energy for animal production; it has been calculated that the energy loss fluctuates between $3 \%$ and $6.5 \%$ on average for cattle fed diets high in concentrates and low-quality pastures, respectively [4]. In tropical climates, feeding of ruminants is largely sustained by using low-quality forages, which in turn increases the production of $\mathrm{CH}_{4}$ [5]. Facing the current climate issues, research has been focused on the reduction of enteric $\mathrm{CH}_{4}$ through feeding practices that alter rumen fermentation, as well as the use of mitigating agents, such as essential oils [6], secondary metabolites [7-9], and some chemical compounds such as organophosphates [6,10] or 3-nitrooxypropanol [11]. In tropical climates, Leucaena leucocephala is a legume species that is highly available and commonly used as fodder for ruminant feeding. Incorporation of L. leucocephala in tropical pastoral systems for meat production has proven to reduce $\mathrm{CH}_{4}$ emissions in cattle $[12,13]$. The use of this tropical legume in ruminant nutrition has been widely implemented due to its high content of crude protein. On the other hand, the effect of L. leucocephala on enteric $\mathrm{CH}_{4}$ reduction is linked to its content of condensed tannins (CT), which form complexes with protein (CT-P) and with polysaccharides, and reduce nutrient degradation in the rumen [14,15]. In addition, some studies propose that CT promote changes in microbial populations [16-18] due to bacteriostatic, bactericidal, and enzyme inhibiting effects that modify rumen fermentation.

The aim of the study was to quantify the effect of increasing levels of dried L. leucocephala leaves on nutrient intake and digestibility, rumen fermentation patterns, $\mathrm{CH}_{4}$ production, and rumen microbial populations in crossbred heifers.

\section{Materials and Methods}

\subsection{Animals, Diet Management, and Experimental Design}

The study was conducted at the Laboratory of Climate Change and Livestock Production at the Faculty of Veterinary Medicine and Animal Science (FMVZ-UADY) of the Autonomous University of Yucatan, Merida, Mexico. Management of experimental animals followed the protocol for animal guidelines and regulations for animal experimentation and welfare of FMVZ-UADY and the experimental protocol was conducted in accordance with the Mexican Official Standard NOM-062-ZOO-1999, technical specifications for the production, care, and use of laboratory animals. Four crossbred heifers (Bos taurus $\times$ Bos indicus) with an average body weight (BW) of $310 \pm 9.6 \mathrm{~kg}$ (mean $\pm \mathrm{SD}$ ) were used. Before the experiment started, heifers were dewormed with Ivermectin ${ }^{\circledR}$ (Pier; Dose: $1 \mathrm{~mL} / 50 \mathrm{~kg}$ BW) and injected intramuscularly with vitamins A, D and E (Vigantol ADE ${ }^{\circledR}$, Bayer manufacturer, Köln, North Rhine-Westphalia, Germany). The heifers were accustomed to the indirect open-circuit respiration chambers for $\mathrm{CH}_{4}$ measurements before starting the experiment. Drinking water was available ad libitum. Heifers were randomly assigned in a $4 \times 4$ Latin square design with four treatments, four heifers, and four periods. Each period lasted for 15 days: 1 to 8 for treatment adaptation and days 9 to 15 for measurements. In order to minimize the residual effect of treatments, after every period, heifers were fed with a diet without dried Leucaena leucocephala leaves (DLL) for 10 days (cleansing).

\subsection{Experimental Diets}

Young stems of leaves of L. leucocephala at 45 days of growth were harvested, the leaves were chopped and dried in the shade for 4 days, and then oven dried in a stove at $40{ }^{\circ} \mathrm{C}$ for four days. Dried L. leucocephala leaves were stored and protected from light until used. Nutrient diet formulation was based on metabolizable energy and protein requirements for ruminants according to the Agriculture and Food Research Council [19], for a predicted daily weight gain of $0.75 \mathrm{~kg}$. Diet formulation was aimed to be isoenergetic, isoproteic, and with similar content of neutral detergent fiber (NDF). Diets were offered to the heifers as total mixed ration, in order to maintain homogeneity in particle size and 
particle type among rations. Formulation and chemical composition of each experimental diet are shown in Table 1 . The inclusions of $0 \%, 12 \%, 24 \%$, and $36 \%$ dry matter (DM) per animal ${ }^{-1}$ day $^{-1}$ of DLL corresponded to treatments $0,1,2$, and 3. Experimental diets were offered at 08:00, considering a dry matter intake (DMI) of $2.5 \%$ of BW [20]. The feed offered was adjusted based on the BW of each animal for every period. Heifers were weighed two days before the beginning of every period and two days after finishing every period.

Table 1. Ingredient composition of experimental diets.

\begin{tabular}{ccccc}
\hline \multirow{2}{*}{ Item } & \multicolumn{4}{c}{ Treatments } \\
\cline { 2 - 5 } & $\mathbf{0}$ & $\mathbf{1}$ & $\mathbf{2}$ & $\mathbf{3}$ \\
\hline Ingredients & $\left(\mathrm{g} \mathrm{kg}^{-1} \mathrm{DM}\right)$ & & \\
Guinea grass hay, ground & 433.3 & 408.0 & 429.3 & 425.3 \\
Corn grain, cracked & 93.3 & 94.7 & 93.3 & 94.7 \\
Soybean meal & 66.7 & 66.7 & 37.3 & 0.00 \\
Leucaena leucocephala dried leaves & 0.00 & 120.0 & 240.0 & 360.0 \\
Wheat bran & 266.7 & 213.2 & 90.7 & 0.00 \\
Sugarcane molasses & 133.3 & 90.7 & 102.7 & 113.3 \\
Mineralized salt & 6.7 & 6.7 & 6.7 & 6.7 \\
\hline \multicolumn{5}{c}{ DM: dry matter } \\
\hline
\end{tabular}

Data collection: sampling procedures and analysis; dry matter intake and apparent digestibility.

Voluntary intake of DM and nutrients in experimental diets were determined as the difference between the amount of nutrients offered and the amount which was refused every day. Samples of feed and refusals were collected and stored every day for posterior chemical analysis. Apparent digestibility was determined by using the method described by [21]. Total production of feces was collected and weighed every day, and an aliquot of $10 \%$ was stored for further analysis. Fecal sample aliquots (last six days during every period) were pooled for treatment each period and were used for chemical analysis.

Estimated nonfiber carbohydrate (NFC) and total digestible nutrients (TDN) were calculated according to Nutrient Requirements of Dairy Cattle [22]. Metabolizable energy (ME) concentration was calculated considering that $1 \mathrm{~kg}$ of TDN is equal to $4.409 \mathrm{Mcal}$ of DE and $1 \mathrm{Mcal}$ of DE is equal to 0.82 Mcal of ME [22].

\subsection{Chemical Analysis}

The collected samples of feed and orts as well as feces were ground and passed through a $1 \mathrm{~mm}$ sieve for analysis according to the methods [23]. DM content of diet, orts, and feces were determined by drying subsamples in a forced-air oven at $105^{\circ} \mathrm{C}$ for $48 \mathrm{~h}$ (constant weight). Nitrogen (N) and crude protein were carried out with Kjeldahl AN 3001 FOSS [23]. Crude protein was calculated as $\mathrm{N} \times 6.25$. Organic matter $(\mathrm{OM})$ content of the samples was determined by combustion in a muffle furnace at $550^{\circ} \mathrm{C}[23]$ and the concentration of NDF (AN 3805 ANKOM, ANKOM Technology, Wayne County, NY, USA) [23] and acid detergent fiber (ADF) (AN 3804 ANKOM) [23] were determined as suggested by Van Soest et al. [24]. Gross energy (GE) was measured using a bomb calorimeter (6400 Parr Instrument Company, Moline, IL, USA). Acid detergent lignin (ADL) was determined in beakers (ANKOM Technology, Wayne County, NY, USA). Ether extract (EE) contents were obtained by the Randall method (SER 148 Solvent extraction unit) [23]. In vitro DM digestibility was determined as suggested by Tilley and Terry [25]. Total phenol (TP) content and total tannins (TT) were determined following the Folin-Ciocalteu method; precipitating tannins with the polyvinylpolypyrrolidone [26], and were expressed as acid-tannin equivalents $\mathrm{g} \mathrm{kg}^{-1} \mathrm{DM}$. CT were quantified using the vanillin assay [27], and were expressed as vanillin equivalents in $\mathrm{g} \mathrm{kg}^{-1} \mathrm{DM}$. 


\subsection{Blood Samples}

Blood samples were collected by jugular venepuncture using 7-mL blood collection tubes (Vacutainer; BD Inc., Oxford, UK) on days 14 and 15 for every period, within four hours postprandial. Blood samples were immediately centrifuged ( $2500 \mathrm{rpm}$ for $10 \mathrm{~min}$ at $4{ }^{\circ} \mathrm{C}$ ) to separate serum, which was stored at $-20^{\circ} \mathrm{C}$ until further analysis. Blood urea nitrogen was determined via a colorimetric assay using a commercial kit (Accutrack S.A. de C.V., CDMX, Mexico).

\subsection{Rumen Fermentation}

Samples of rumen content were taken from animals on days 14 and 15 of every period, within four hours postprandial. Approximately 1.2 L of rumen fluid was taken from each heifer by inserting an esophageal tube [28]. The samples were filtered through four layers of cheesecloth. Three sub-samples were taken. Metaphosphoric acid was added to the first sub-sample 1:5 $(\mathrm{v} / \mathrm{v})$ to preserve the sample at $-80^{\circ} \mathrm{C}$ for volatile fatty acids (VFA) analysis. VFA proportions in rumen liquid were determined by gas chromatography (7890A GC system Agilent Technologies Inc, Santa Clara, CA, USA), equipped with a flame ionization detector [29]. Rumen $\mathrm{pH}$ was measured immediately after obtaining the sample with a portable potentiometer (HANNA ${ }^{\circledR}$ Instruments, Woonsocket, RI, USA) in the second sub-sample. The third subsample was preserved at $-80^{\circ} \mathrm{C}$ for ruminal microbial deoxyribonucleic acid (DNA) extraction.

\subsection{Microbial Quantification}

\subsubsection{Ruminal Microbial DNA Extraction}

The deoxyribonucleic acid extraction was carried out using the method described by Rojas-Herrera [30]. DNA concentration was calculated using a NanoDrop 2000 (Thermo Scientific, Waltham, MA, USA), and the DNA integrity was confirmed by agarose gel electrophoresis. DNA samples were then stored at $-80^{\circ} \mathrm{C}$ until analysis.

\subsubsection{Quantitative Real-Time Polymerase Chain Reaction (qPCR)}

The qPCR was applied to quantify the bacterial, protozoal, and methanogenic archaeal populations in the rumen by measuring the absolute quantity of the targeted DNA fragments by a reference to a standard curve constructed with a plasmid containing the target insert. The domain bacteria primers used were BAC338F and BAC805R [31], methanogen primers were Met630F and Met803R [32], and protozoal primers were Oph-151F and Ento-472R [33] (Table 2). The qPCR amplifications for the quantification of target ruminal microbial genes were performed using a Rotor-Gene $Q$ (Qiagen, Hilden, Germany). Chemical reagent Go Taq Green Master Mix (Promega, Madison, WI, USA) was used following the manufacturer's instructions.

Table 2. Oligonucleotide primers used for the quantitative polymerase chain reaction.

\begin{tabular}{|c|c|c|c|}
\hline Primer & Sequence & $\begin{array}{l}\text { Alignment } \\
\text { Temperature }\end{array}$ & $\begin{array}{c}\text { Amplification } \\
\text { Efficiency }\end{array}$ \\
\hline BAC338F & 5'-ACT CCT ACG GGA GGC AG-3' & \multirow{2}{*}{$57^{\circ} \mathrm{C}$} & \multirow[t]{2}{*}{1.99} \\
\hline BAC $805 R$ & $5^{\prime}$-GAC TAC CAG GGT ATC TAA TCC-3' & & \\
\hline Met630F & 5'-GGA TTA GAT ACC CSG GTA GT-3' & \multirow{2}{*}{$57^{\circ} \mathrm{C}$} & \multirow[t]{2}{*}{2} \\
\hline Met803R & $5^{\prime}$-GTT GAR TCC AAT TAA ACC GCA-3' & & \\
\hline Oph-151F & $5^{\prime}$-GAG CTA ATA CAT GCT AAG GC-3' & \multirow{2}{*}{$55^{\circ} \mathrm{C}$} & \multirow[t]{2}{*}{2} \\
\hline Ento-472R & $5^{\prime}$-CCC TCA CTA CAA TCG AGA TTT AAG G-3' & & \\
\hline
\end{tabular}

qPCR: quantitative polymerase chain reaction. 
Each gene was cloned separately by using PGEM $^{\circledR}$-T Easy Vector System and ligation using $2 \times$ Rapid Ligation buffer (Promega, Madison, WI, USA) according to the manufacturer's instructions. Then, the recombinant vector was transformed into competent $E$. coli cells with ampicillin and X-gal/IPTG. Transformed positive colonies were picked and processed for plasmid isolation. Plasmid purification was done using a Wizard ${ }^{\circledR}$ Plus SV Minipreps DNA Purification System (Promega, Madison, WI, USA.). Presence of the insert in the recombinant clones was confirmed by restriction digestion and digested products were detected by agarose gel electrophoresis. Plasmid DNA concentrations were measured using a NanoDrop 2000 (Thermo Scientific, Waltham, MA, USA) and copy numbers were calculated using the following equation:

$$
\text { Number of copies } / \mu \mathrm{L}=\frac{6.022 \times 10^{23}\left(\frac{\text { molecules }}{\text { mole }}\right) * \text { plasmid concentrations }\left(\frac{g}{\mu \mathrm{L}}\right)}{\text { number of bases } * 660 \text { daltons }}
$$

To construct the standard curve, a tenfold series dilution $\left(10^{2}\right.$ to $\left.10^{10}\right)$ was performed for each target gene. Each standard curve and sample was analyzed in triplicate for absolute quantification. The amplification efficiency $(E)$ was determined by the slope $(s)$ of linear regression of the standard curve. Amplification efficiency was established using the following equation [34]:

$$
E=10^{(-1 / s)}
$$

\subsection{Methane Production}

Emission of $\mathrm{CH}_{4}$ was measured using individual indirect open-circuit respiration chambers [35] with a methane measurement system (Sable Systems International ${ }^{\circledR}$, Las Vegas, NV, USA). Heifers remained in the respiration chambers for $23 \mathrm{~h}$ per day. Each heifer was in the chamber for four days receiving the same treatment during the period. Temperature and relative humidity inside the chambers were kept at $23{ }^{\circ} \mathrm{C}$ and $55 \%$, respectively. Data were extrapolated to $24 \mathrm{~h}$ using Expe Data ${ }^{\circledR}$ software (Sable Systems International ${ }^{\circledR}$, Las Vegas, NV, USA). The infrared $\mathrm{CH}_{4}$ analyzer was calibrated before each experimental period. Methane concentrations were transformed to energy taking into account the heat combustion of $\mathrm{CH}_{4}\left(55.65 \mathrm{MJ} \mathrm{kg}^{-1}\right)$ [4]. Moreover, methane loss was expressed in absolute terms as GE (Gross energy, $\mathrm{MJ} \mathrm{d}^{-1}$ ) and also emission of $\mathrm{CH} 4$ as a percentage of GEI (Gross energy intake, Ym). Additionally, the estimate of the emission factor (EF) of $\mathrm{CH}_{4} \mathrm{~kg}$ animal $^{-1}$ year $^{-1}$ was calculated according to [4].

\subsection{Nitrous Oxide Emissions}

Estimated nitrous oxide $\left(\mathrm{N}_{2} \mathrm{O}\right)$ emissions from feces of heifers were calculated with fecal $\mathrm{N}$ excretion and according to its volatilization rate for Latin America [4] with the equations 10.25 (direct $\mathrm{N}_{2} \mathrm{O}$ emissions from manure management), 10.28 ( $\mathrm{N}$ losses due to leaching from manure management system), and 10.29 (indirect $\mathrm{N}_{2} \mathrm{O}$ emissions due to leaching from manure management) of the [4].

Both $\mathrm{CH}_{4}$ production and estimated $\mathrm{N}_{2} \mathrm{O}$ emissions were converted to $\mathrm{CO}_{2}$ equivalents $\left(\mathrm{CO}_{2}\right.$-eq) using global warming potential values of 28 and 265, respectively [4].

\subsection{Statistical Analyses}

Statistical analyses were carried out on data of DM intake, apparent digestibility, fermentation parameters, blood metabolites, $\mathrm{CH}_{4}$ production, and rumen microorganism population. Data of bacteria, methanogen, and protozoa (cells $\mathrm{mL}^{-1}$ of ruminal liquor) were transformed to $\log _{10}$. All data were subjected to analysis of variance for a $4 \times 4$ Latin square design, using the mixed procedure of the SAS ${ }^{\circledR}$ 9. Software (SAS Inc., Cary, NC, USA.) [36]. The statistical model was Yijk $=\mu+\mathrm{Pi}+\mathrm{Aj}+$ Tk + Eijk; where: $Y$ is the dependent variable, $\mu$ is the general mean, $P$ is the effect of period, $A$ is the random effect of animal, $\mathrm{T}$ is the effect of treatment, and $\mathrm{E}$ is the random residual error. Results were 
compared with the procedure LSmeans test, whereas orthogonal contrasts were performed to evaluate the effect of treatments [36].

\section{Results}

\subsection{Chemical Analysis of Experimental Diets}

The chemical analyses of experimental diets are shown in Table 3. Although the aim of diet formulation was to obtain isoproteic and isoenergetic diets, it was evident that the diet without inclusion of DLL had a lower content of CP and GE in comparison with the other treatments. In addition, the diets were not homogeneous in the contribution of NDF. In the case of ADF and ADL, these were increased as a result of increasing the inclusion of DLL in the diets. The concentration of ADF and ADL in treatment with DLL showed a trend higher than treatment 0 . These could be related to a minor content of OM and reduction of in vitro DM digestibility. On the other hand, the concentrations of fat and secondary metabolites (total phenols, total tannins, and CT) in the diets were increased as a result of a higher level of inclusion of DLL in diets. Estimation of NFC showed the lowest content in treatment 3 compared to the other treatments.

Table 3. Chemical composition of experimental diets.

\begin{tabular}{|c|c|c|c|c|}
\hline \multirow{2}{*}{ Item } & \multicolumn{4}{|c|}{ Treatments } \\
\hline & 0 & 1 & 2 & 3 \\
\hline \multicolumn{5}{|c|}{ Chemical composition $\left(\mathrm{g} \mathrm{kg}^{-1} \mathrm{DM}\right)$} \\
\hline Organic matter & 933 & 931 & 925 & 919 \\
\hline Crude protein & 109.7 & 134.6 & 136.4 & 137.8 \\
\hline Neutral detergent fiber & 585.6 & 554.4 & 537.3 & 594.2 \\
\hline Acid detergent fiber & 295.4 & 312.1 & 333.1 & 352.4 \\
\hline Acid detergent lignin & 55.5 & 74.2 & 70.4 & 91.3 \\
\hline Ether extract & 11.7 & 16.3 & 23.2 & 22.3 \\
\hline Gross energy (MJ kg $\left.{ }^{-1} \mathrm{DM}\right)$ & 17.8 & 18.0 & 18.0 & 18.1 \\
\hline Total phenols a & 0.42 & 9.6 & 22.8 & 26.4 \\
\hline Total tannins ${ }^{a}$ & 0.04 & 4.3 & 13.1 & 15.1 \\
\hline Condensed tannins ${ }^{b}$ & 0.0 & 2.7 & 8.2 & 12.3 \\
\hline In vitro $\mathrm{DM}$ digestibility $\left(\mathrm{g} \mathrm{kg}^{-1} \mathrm{DM}\right)$ & 676 & 654 & 637 & 617 \\
\hline \multicolumn{5}{|c|}{ Estimated values } \\
\hline NFC & 22.1 & 22.1 & 22.3 & 16.1 \\
\hline
\end{tabular}

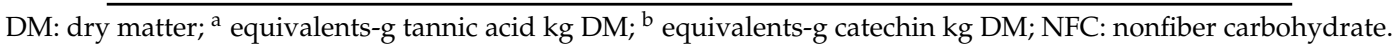

\subsection{Feed Intake and Apparent Digestibility}

The effect of DLL supplementation on intake and apparent digestibility is presented in Table 4. No significant effects were found in the DMI, OM intake (OMI), and GEI. On the other hand, the intakes of CP and ADF increased with a higher level of DLL. Crude protein intake was 21.7\%, 28.3\%, and $28.3 \%$ higher for treatments 1,2 , and 3 than that for treatment 0 . In contrast, the consumption of NDF was lower by $5 \%$ for treatments 1 and 2 compared to treatments 0 and 3 . Consumption of ADL was different between treatments 1 and 2. Intake of TP, TT, and CT increased linearly as DLL inclusion increased. For CT, an increase corresponding to $2.7,8.2$, and $12.3 \mathrm{~g} \mathrm{~kg}^{-1}$ of DMI for treatments at 1,2 , and 3 was observed compared with treatment 0 . Apparent digestibility of OM and NDF decreased with increasing DLL in the rations. The effect of reduction in digestible OM and NDF were of $1.5 \%, 8.8 \%$, $13.2 \%$ and $12.7 \%, 22.5 \%, 13.4 \%$ for treatments 1,2 , and 3 , respectively against treatment 0 . On the other hand, digestible energy (DE) decreased to $8.3 \mathrm{MJ} \mathrm{d}^{-1}$ with treatment 3 versus treatment 0 . In contrast, the apparent digestibility of CP increased compared to the control by $25 \%$ and $14 \%$ for treatment 1 and 2. In the same way, the digestibility of ADF increased by $20 \%$ in treatment 2 in contrast to treatment 0 . 
Table 4. Effect of dried L. leucocephala leaves supplementation on intake and apparent digestibility in heifers.

\begin{tabular}{|c|c|c|c|c|c|c|c|c|c|}
\hline \multicolumn{5}{|c|}{ Treatments } & \multirow{2}{*}{ SE } & \multirow{2}{*}{$p$} & \multicolumn{3}{|c|}{ Contrast } \\
\hline Item & 0 & 1 & 2 & 3 & & & $\mathbf{L}$ & $\mathbf{Q}$ & $\mathrm{C}$ \\
\hline & \multicolumn{9}{|c|}{ Intake $\left(\mathrm{kg} \mathrm{d}^{-1}\right)$} \\
\hline DM & 8.36 & 8.32 & 8.63 & 8.54 & 0.13 & 0.169 & 0.098 & 0.8176 & 0.1226 \\
\hline $\mathrm{OM}$ & 7.8 & 7.74 & 7.98 & 7.85 & 0.12 & 0.340 & 0.365 & 0.694 & 0.136 \\
\hline $\mathrm{CP}$ & $0.92^{\mathrm{c}}$ & $1.12^{b}$ & $1.18^{\mathrm{a}}$ & $1.18^{\mathrm{a}}$ & 0.02 & $<0.0001$ & $<0.0001$ & 0.0004 & 0.231 \\
\hline NDF & $4.9^{\mathrm{a}}$ & $4.61^{b}$ & $4.64^{b}$ & $5.07^{\mathrm{a}}$ & 0.08 & 0.0027 & 0.065 & 0.0006 & 0.695 \\
\hline $\mathrm{ADF}$ & $2.47^{\mathrm{d}}$ & $2.6^{c}$ & $2.87^{b}$ & $3.01^{\mathrm{a}}$ & 0.04 & $<0.0001$ & $<0.0001$ & 0.882 & 0.067 \\
\hline GE & 149 & 150 & 156 & 155 & 2.43 & 0.078 & 0.0256 & 0.572 & 0.181 \\
\hline $\mathrm{EE}$ & $0.155^{\mathrm{a}}$ & $0.156^{\mathrm{a}}$ & $0.101^{b}$ & $0.100^{b}$ & 0.02 & 0.029 & 0.008 & 0.934 & 0.105 \\
\hline ADL & 0.615 & 0.609 & 0.631 & 0.623 & 0.01 & 0.114 & 0.106 & 0.809 & 0.057 \\
\hline PT & $0.035^{\mathrm{d}}$ & $0.08^{c}$ & $0.197^{b}$ & $0.226^{\mathrm{a}}$ & 0.003 & $<0.0001$ & $<0.0001$ & 0.011 & $<0.0001$ \\
\hline $\mathrm{TT}$ & $0.003^{\mathrm{d}}$ & $0.036^{c}$ & $0.113^{b}$ & $0.129^{a}$ & 0.002 & $<0.0001$ & $<0.0001$ & 0.001 & $<0.0001$ \\
\hline \multirow[t]{2}{*}{$\mathrm{CT}$} & $0.00^{\mathrm{d}}$ & $0.023^{c}$ & $0.07^{b}$ & $0.104^{a}$ & 0.002 & $<0.0001$ & $<0.0001$ & 0.003 & 0.0003 \\
\hline & \multicolumn{9}{|c|}{ Nutrient apparent digestibility (g kg $\left.{ }^{-1} \mathrm{DMI}\right)$} \\
\hline $\mathrm{OM}$ & $481.9^{a}$ & $474.7^{\mathrm{a}}$ & $439.3^{b}$ & $418.4^{b}$ & 12.32 & 0.006 & 0.001 & 0.463 & 0.315 \\
\hline $\mathrm{CP}$ & $60^{c}$ & $74.9^{\mathrm{a}}$ & $68.5^{\mathrm{b}}$ & $61.9^{c}$ & 1.6 & 0.0003 & 0.928 & $<0.0001$ & 0.005 \\
\hline NDF & $238.2^{\mathrm{a}}$ & $208.0^{\mathrm{b}}$ & $184.6^{c}$ & $206.4^{b c}$ & 9.51 & 0.008 & 0.007 & 0.008 & 0.247 \\
\hline $\mathrm{ADF}$ & 79.5 & 89.9 & 95.5 & 85.9 & 6.02 & 0.157 & 0.244 & 0.057 & 0.607 \\
\hline \multirow[t]{2}{*}{$\mathrm{DE}$} & $8.8^{\mathrm{a}}$ & $8.7^{\mathrm{a}}$ & $8.2^{a b}$ & $7.8^{b}$ & 0.25 & 0.020 & 0.004 & 0.360 & 0.594 \\
\hline & \multicolumn{9}{|c|}{ Estimated values } \\
\hline TDN & 0.546 & 0.541 & 0.529 & 0.480 & & & & & \\
\hline $\mathrm{ME}$ & 8.26 & 8.18 & 8.00 & 7.26 & & & & & \\
\hline
\end{tabular}

DM: dry matter; DMI: dry matter intake; OM: organic matter; CP: crude protein; NDF: neutral detergent fiber; ADF: acid detergent fiber; GE: gross energy $\left(\mathrm{MJ} \mathrm{d}^{-1}\right.$ ); EE: ether extract; TP: total phenols; TT: total tannins; CT: condensed tannins; ADL: acid detergent lignin; DE: digestible energy (MJ kg-1 DMI); TDN: total digestible nutrients $\left(\mathrm{kg}^{-1}\right.$ DMI); ME: metabolizable energy (MJ kg ${ }^{-1} \mathrm{DMI}$ ). Means in the same row with different superscript letters differ $(p<0.05)$; SE: standard error; surface response: L: linear contrast; Q: quadratic contrast; C: cubic contrast.

\subsection{Fermentation Parameters}

Rumen fermentation parameters are shown in Table 5. Ruminal $\mathrm{pH}$ was not affected $(p>0.05)$ by the inclusion of DLL in the diets. Molar concentrations and the ratio of acetic acids in rumen liquor were affected significantly by treatments $(p<0.05)$.

Table 5. Effect of dried L. leucocephala leaves supplementation on fermentation in the rumen of heifers.

\begin{tabular}{|c|c|c|c|c|c|c|c|c|c|}
\hline \multicolumn{5}{|c|}{ Treatments } & \multirow{2}{*}{ SE } & \multirow{2}{*}{$p$} & \multicolumn{3}{|c|}{ Contrast } \\
\hline Item & 0 & 1 & 2 & 3 & & & $\mathbf{L}$ & $\mathbf{Q}$ & $\mathrm{C}$ \\
\hline Rumen $\mathrm{pH}$ & 6.4 & 6.5 & 6.5 & 6.5 & 0.13 & 0.815 & 0685 & 0.522 & 0.604 \\
\hline Total VFA mMol L ${ }^{-1}$ & 79.9 & 80.4 & 75.4 & 66.9 & 8.46 & 0.36 & 0.128 & 0.435 & 0.975 \\
\hline $\begin{array}{l}\text { Acetic:propionic acid } \\
\text { ratio } \mathrm{mMol} \mathrm{L}^{-1}\end{array}$ & $2.68^{\mathrm{b}}$ & $2.74^{\mathrm{b}}$ & $3.42^{\mathrm{a}}$ & $3.38^{a}$ & 0.25 & 0.04 & 0.013 & 0.805 & 0.145 \\
\hline \multicolumn{10}{|c|}{ Molar proportions of VFA (\%) } \\
\hline Acetic acid & $61.0^{b}$ & $61.0^{\mathrm{b}}$ & $65.4^{\mathrm{ab}}$ & $67.4^{\mathrm{a}}$ & 1.8 & 0.025 & 0.005 & 0.446 & 0.298 \\
\hline Propionic acid & 22.8 & 23.1 & 19.3 & 20.0 & 1.7 & 0.157 & 0.065 & 0.871 & 0.171 \\
\hline Butyric acid & 10.9 & 13.1 & 10.7 & 10.8 & 2.98 & 0.818 & 0.772 & 0.619 & 0.481 \\
\hline Isobutyric acid & 0.62 & 0.59 & 1.42 & 0.42 & 0.65 & 0.480 & 0.920 & 0.334 & 0.241 \\
\hline Valeric acid & 1.27 & 1.32 & 1.69 & 0.91 & 0.45 & 0.464 & 0.646 & 0.244 & 0.350 \\
\hline Isovaleric acid & 3.23 & 0.72 & 1.36 & 0.38 & 1.86 & 0.479 & 0.226 & 0.582 & 0.449 \\
\hline
\end{tabular}

VFA: Volatile fatty acids. Means in the same row with different superscript letters differ $(p<0.05)$; SE: standard error; surface response: L: linear contrast; Q: quadratic contrast; C: cubic contrast. 


\subsection{Fecal Nitrogen Excretion}

The values of ingested and fecal excreted nitrogen $(\mathrm{N})$ are shown in Table 6. Ingested $\mathrm{N}(\mathrm{Ni})$ show differences $(p<0.05)$ among treatments. However, the concentration of blood nitrogen urea (BUN) increased $(p<0.05)$ in treatments 1 and 2 compared to the other treatments, while fecal $\mathrm{N}$ excretion (Nf) increased linearly $(p<0.0001)$ as DLL increased in the diet.

Table 6. Indicators of the flow of nitrogen consumed by heifers fed Leucaena leucocephala.

\begin{tabular}{|c|c|c|c|c|c|c|c|c|c|}
\hline \multicolumn{5}{|c|}{ Treatments } & \multirow{2}{*}{ SE } & \multirow{2}{*}{$p$} & \multicolumn{3}{|c|}{ Contrast } \\
\hline Item & 0 & 1 & 2 & 3 & & & $\mathbf{L}$ & $\mathbf{Q}$ & $\mathrm{C}$ \\
\hline Ratio CP:TDN & 0.210 & 0.249 & 0.258 & 0.287 & & & & & \\
\hline Ratio TDN:CP & 4.98 & 4.02 & 3.88 & 3.48 & & & & & \\
\hline $\mathrm{N}$ intake $\left(\mathrm{g} \mathrm{d}^{-1}\right)$ & $146.9^{b}$ & $179.1^{\mathrm{a}}$ & $188.4^{\mathrm{a}}$ & $188.2^{\mathrm{a}}$ & 3.18 & $<0.0001$ & $<0.00014$ & 0.0004 & 0.231 \\
\hline BUN (mg dL $\left.{ }^{-1}\right)$ & $9.89^{c}$ & $10.96^{b}$ & $11.72^{\mathrm{a}}$ & $9.95^{c}$ & 0.26 & 0.001 & 0.314 & $<0.001$ & 0.036 \\
\hline $\mathrm{N}$ fecal $\left(\mathrm{g} \mathrm{d}^{-1}\right)$ & $67.4^{\mathrm{d}}$ & $80.1^{\mathrm{C}}$ & $93.7^{\mathrm{b}}$ & $103.8^{\mathrm{a}}$ & 2.4 & $<0.0001$ & $<0.0001$ & 0.470 & 0.589 \\
\hline Ratio N fecal: $\mathrm{N}$ intake & 0.46 & 0.45 & 0.50 & 0.55 & & & & & \\
\hline Ratio CP:DOM & 0.228 & 0.284 & 0.311 & 0.329 & & & & & \\
\hline
\end{tabular}

CP: crude protein; TDN: total digestible nutrients; N: nitrogen; BUN: concentration of blood nitrogen urea; DOM: digestible organic matter; ${ }^{\text {a-d }}$ Means in the same row with different superscript letters differ $(p<0.05)$; SE: standard error; surface response: L: linear contrast; Q: quadratic contrast; C: cubic contrast.

\subsection{Ruminal Microorganism Population}

The effect of supplementation of DLL on ruminal microorganism populations is summarized in Table 7. Inclusion of DLL showed not effect $(p>0.05)$ on protozoal, bacterial, and archaeal populations. The ratio of methanogens:bacterial population was not altered $(p>0.05)$.

Table 7. Estimation of ruminal microbial population by quantitative polymerase chain reaction.

\begin{tabular}{|c|c|c|c|c|c|c|c|c|c|}
\hline \multicolumn{5}{|c|}{ Treatments } & \multirow{2}{*}{ SE } & \multirow{2}{*}{$p$} & \multicolumn{3}{|c|}{ Contrast } \\
\hline Item & 0 & 1 & 2 & 3 & & & $\mathbf{L}$ & $Q$ & $\mathrm{C}$ \\
\hline \multicolumn{10}{|c|}{ qPCR Microbial population } \\
\hline Protozoa $\log _{10}$ cell ml ${ }^{-1}$ & 4.52 & 4.77 & 5.31 & 5.06 & 0.34 & 0.209 & 0.092 & 0.329 & 0.353 \\
\hline Bacteria $\log _{10}$ cell $\mathrm{ml}^{-1}$ & 9.01 & 9.29 & 9.40 & 9.22 & 0.13 & 0.133 & 0.147 & 0.058 & 0.812 \\
\hline Methanogens $\log _{10}$ cell $\mathrm{ml}^{-1}$ & 6.40 & 6.32 & 6.77 & 6.71 & 0.29 & 0.395 & 0.182 & 0.963 & 0.304 \\
\hline Methanogen:bacteria & 0.71 & 0.68 & 0.72 & 0.73 & 0.035 & 0.556 & 0.433 & 0.459 & 0.368 \\
\hline
\end{tabular}

qPCR: quantitative polymerase chain reaction. Means in the same row with different superscript letters differ $(p<0.05)$; SE: standard error; surface response: L: linear contrast; Q: quadratic contrast; C: cubic contrast

\subsection{Methane Production.}

Methane production is shown in Table 8. Inclusion of DLL in the diets resulted in a significant decrease $(p<0.001)$ in $\mathrm{CH}_{4}$ production. Methane reductions were of $6.2 \%, 11 \%$, and $19.6 \%$ (where $100 \%$ is equivalent to the emission of $\mathrm{CH}_{4}$ measured without the inclusion of DLL or treatment 0 ) corresponding to an increase of DLL in the diet. In this study, the production of $\mathrm{CH}_{4} \mathrm{~g} \mathrm{~kg}^{-1} \mathrm{DMI}$ was affected negatively $(p<0.001)$ in treatments 2 and 3 , which corresponds to a reduction of $13.5 \%$ and $20.7 \%$, respectively. Reduction of $\mathrm{CH}_{4} \mathrm{~g} \mathrm{~kg}^{-1}$ of $\mathrm{DM}, \mathrm{CH}_{4} \mathrm{~g} \mathrm{~kg}^{-1}$ of digestible $\mathrm{OM}$ and $\mathrm{CH}_{4} \mathrm{~g}$ $\mathrm{kg}^{-1}$ of digestible NDF did not show significant differences $(p>0.05)$ among treatments. In contrast, $\mathrm{CH}_{4} \mathrm{~g} \mathrm{~kg}^{-1}$ of digestible CP decreased significantly $(p<0.001)$ by $25 \%$ on average in all treatments containing DLL against treatment 0 . 
Table 8. Effect of supplements of dried L. leucocephala leaves on enteric $\mathrm{CH}_{4}$ production in heifers.

\begin{tabular}{|c|c|c|c|c|c|c|c|c|c|}
\hline \multicolumn{5}{|c|}{ Treatments } & \multirow{2}{*}{ SE } & \multirow{2}{*}{$p$} & \multicolumn{3}{|c|}{ Contrast } \\
\hline Item & 0 & 1 & 2 & 3 & & & L & $\mathbf{Q}$ & $\mathrm{C}$ \\
\hline \multicolumn{10}{|c|}{ Methane } \\
\hline $\mathrm{CH}_{4}\left(\mathrm{~g} \mathrm{~d}^{-1}\right)$ & $174.2^{\mathrm{a}}$ & $162.9^{b}$ & $154.8^{\mathrm{b}}$ & $140.0^{c}$ & 3.73 & 0.001 & 0.0002 & 0.581 & 0.497 \\
\hline $\mathrm{CH}_{4}(\mathrm{DMI})$ & $20.8^{a}$ & $19.6^{\mathrm{a}}$ & $17.9^{b}$ & $16.4^{\mathrm{c}}$ & 0.57 & 0.0012 & 0.0002 & 0.672 & 0.716 \\
\hline \multicolumn{10}{|c|}{ Methane $\mathrm{g} \mathrm{kg}^{-1}$ of digestible fractions intake } \\
\hline $\mathrm{CH}_{4}(\mathrm{DM})$ & 44.8 & 42.5 & 40.6 & 39.0 & 2.37 & 0.181 & 0.040 & 0.860 & 0.994 \\
\hline $\mathrm{CH}_{4}(\mathrm{OM})$ & 44.1 & 42.1 & 40.8 & 39.4 & 2.19 & 0.274 & 0.068 & 0.869 & 0.910 \\
\hline $\mathrm{CH}_{4}(\mathrm{CP})$ & $353.4^{\mathrm{a}}$ & $265.8^{b}$ & $261.9^{b}$ & $266.1^{b}$ & 13.68 & 0.001 & 0.0009 & 0.0032 & 0.131 \\
\hline $\mathrm{CH}_{4}$ (NDF) & 90.4 & 98.4 & 97.1 & 80.1 & 6.47 & 0.097 & 0.169 & 0.034 & 0.767 \\
\hline \multicolumn{10}{|c|}{ Estimated of methane as energy loss } \\
\hline $\mathrm{Ym}$ & $6.5^{\mathrm{a}}$ & $6.07^{\mathrm{b}}$ & $5.54^{\mathrm{c}}$ & $5.05^{\mathrm{d}}$ & 0.17 & 0.0008 & 0.0001 & 0.841 & 0.827 \\
\hline $\mathrm{CH}_{4}\left(\mathrm{MJ} \mathrm{d}^{-1}\right)$ & $9.6^{\mathrm{a}}$ & $9.0^{\mathrm{b}}$ & $8.6^{\mathrm{b}}$ & $7.7^{\mathrm{c}}$ & 0.23 & 0.001 & 0.0002 & 0.581 & 0.497 \\
\hline $\mathrm{EF}$ & $63.5^{\mathrm{a}}$ & $59.4^{b}$ & $56.5^{\mathrm{b}}$ & $51.1^{\mathrm{c}}$ & 1.56 & 0.001 & 0.0002 & 0.581 & 0.497 \\
\hline
\end{tabular}

$\mathrm{CH}_{4}$ : methane: $\mathrm{CH}_{4}$ d: $\mathrm{CH}_{4} \mathrm{~g} \mathrm{~d}^{-1}$; $\mathrm{CH}_{4}$ DMI: $\mathrm{CH}_{4} \mathrm{~g} \mathrm{~kg}^{-1}$ Dry Matter Intake; $\mathrm{CH}_{4} \mathrm{DM}: \mathrm{CH}_{4} \mathrm{~g} \mathrm{~kg}^{-1}$ Dry Matter; $\mathrm{CH}_{4} \mathrm{OM}: \mathrm{CH}_{4} \mathrm{~g} \mathrm{~kg}^{-1}$ Organic Matter; $\mathrm{CH}_{4} \mathrm{PC}: \mathrm{CH}_{4} \mathrm{~g} \mathrm{~kg}^{-1}$ Crude Protein; $\mathrm{CH}_{4} \mathrm{NDF}: \mathrm{CH}_{4} \mathrm{~g} \mathrm{~kg}^{-1}$ Neutral Detergent Fiber; GEI: gross energy intake; $\mathrm{Ym}: \mathrm{CH}_{4} \mathrm{MJ} \mathrm{d}^{-1}$, expressed as percentage of gross energy intake; $\mathrm{EF} \mathrm{CH}_{4}$ emission factor, $\mathrm{kg} \mathrm{CH}_{4}$ animal $^{-1}$ year ${ }^{-1}$; Means in the same row with different superscript letters differ $(p<0.05)$; SE: standard error; surface response: L: linear contrast; Q: quadratic contrast; C: cubic contrast.

Energy loss as $\mathrm{CH}_{4}$ during fermentation was $6.2 \%, 11.3 \%$, and $19.6 \% \mathrm{MJ} \mathrm{d}^{-1}$ of GEI for treatments 1,2 , and 3 , respectively versus treatment 0 . These effects showed a linear $(p<0.01)$ reduction of energy correlated negatively with DLL inclusion. In the same case, Ym decreased $(p<0.01)$ by $6.6 \%, 14.8 \%$, and $22.3 \%$ in treatments 1,2 , and 3 , respectively versus treatment 0 . The emission factor (EF) of $\mathrm{CH}_{4}$ $\mathrm{kg}$ animal $^{-1}$ year $^{-1}$ decreased linearly $(p<0.01)$ in response to inclusion of DLL. Treatments 1,2 , and 3 reduced $\mathrm{EF}$ by $6.5 \%, 11.1 \%$, and $19.6 \%$ in contrast to treatment 0 .

\subsection{Effect of DLL on Greenhouse Gas Emissions}

Estimated global warming potential (GWP) of $\mathrm{CH}_{4}$ and $\mathrm{N}_{2} \mathrm{O}$ in heifers fed DLL can be observed in Table 9. Estimated GWP from $\mathrm{CH}_{4}$ as $\mathrm{CO}_{2}$-eq $\mathrm{d}^{-1}$ showed a decreasing tendency as DLL increased in the diets. In contrast, all treatments with DLL showed an increase of estimated GWP through $\mathrm{N}_{2} \mathrm{O} \mathrm{CO}_{2}$-eq $\mathrm{d}^{-1}$ from nitrogen excreted through feces against the treatment without DLL. However, according to the estimate of total GWP $\left(\mathrm{CH}_{4}\right.$ and $\left.\mathrm{N}_{2} \mathrm{O}\right)$ all treatments with DLL showed a total GHG emission mitigation potential compared to the diet without DLL or treatment 0.

Table 9. Estimate global warming potential in heifers fed with dried L. leucocephala leaves.

\begin{tabular}{|c|c|c|c|c|}
\hline \multicolumn{5}{|c|}{ Treatments } \\
\hline Global warming potential & $\mathbf{0}$ & 1 & 2 & 3 \\
\hline $\mathrm{CH}_{4}\left(\mathrm{CO}_{2}\right.$-eq kg d $\left.\mathrm{kg}^{-1}\right)$ & 4.88 & 4.56 & 4.33 & 3.92 \\
\hline $\mathrm{N}_{2} \mathrm{O}\left(\mathrm{CO}_{2}\right.$-eq kg d $\left.{ }^{-1}\right)$ & 1.17 & 1.39 & 1.62 & 1.79 \\
\hline \multicolumn{5}{|c|}{ Total global warming potential } \\
\hline $\mathrm{CO}_{2}$-eq kg d $\mathrm{kg}^{-1}$ & 6.05 & 5.95 & 5.95 & 5.71 \\
\hline
\end{tabular}

$\mathrm{CH}_{4}$; methane; $\mathrm{N}_{2} \mathrm{O}$ nitrous oxide; $\mathrm{CO}_{2}$-eq; carbon dioxide equivalents.

\section{Discussion}

The effects of L. leucocephala consumption on intake and digestibility of feed, and on enteric $\mathrm{CH}_{4}$ mitigation, are linked to its content of CT. Condensed tannins have been widely studied for their effects in animal nutrition. It is generally accepted to use the term 'anti-nutritional effect' to describe the reduction of palatability leading to a reduced ingestion of feed and a lower nutrient digestibility. Both 
effects are related to the astringency generated by the capacity of tannins to establish stable bonds with dietary components [37]. In this study, the DLL treatments contained $0 \%, 0.28 \%, 0.82 \%$, and $1.23 \%$ CT in the total diet. None of the inclusion levels of L. leucocephala affected DMI or OMI. Previous studies obtained similar results [8,9], but did not observe any effect on DMI with CT doses $\leq 2 \%$. Ruminants in the tropics are exposed to tannin containing forages, leading to selectivity in their consumption or adaption to these conditions. Some studies have suggested that ruminants possess proteins with a high content of amino acids such as proline [38] in their saliva, which are more likely to bind with CT. Thus, allowing ruminants to reduce or block the effect of astringency which could lead to a reduction in feed intake.

In regard to $\mathrm{CP}$ and $\mathrm{ADF}$ consumption, significant increments were shown with DLL supplementation which was related to the concentration of these components in the diet (Table 3). In the case of legumes such as L. leucocephala there has been reported greater amount of CP compared to tropical grass [39]. On the other hand, NDF and ADL intakes remained unchanged or decreased compared to those for treatment 0 . This observation is contrary to previous studies where no effect on consumption of NDF and ADF with doses $\leq 2 \%$ CT was observed $[8,40]$.

Apparent nutrient digestibility was affected by the level of DLL in the ration. Digestibility of OM and NDF showed a linear reduction. These findings may be associated with in vitro DM digestibility (Table 4) and total digestible nutrients (TDN) which showed a comparable decline with higher inclusions of DLL. This effect can be explained by the ADL contained in DLL. Similar reductive effects were reported in other studies for digestibility of DM (DDM) [41,42], digestible OM (DOM) [39], and digestible NDF [42]. However, results reported by other authors differ from the above, showing increases in DOM, NDF, and digestible ADF [8]. It also indicates increases in digestibility of OM and NDF [43]. All results quoted in this section were derived from in vivo studies and correspond to a dose of $\leq 2 \%$ CT. However, the source of CT differs in some of the studies, which could account for the heterogeneity of results. Genotype, species, variety, and growth stage of the plant material are associated with differences in the chemical structure and molecular weight of CT as key characteristics determining their capacity to precipitate proteins $[41,44]$ which could affect the digestibility of feed. Another aspect that has to be taken into account to explain the differences regarding digestibility is the ability of CT to attach to cellulose and hemicelluloses as well as to enzymes of microbial origin [17,45]. Consequently, it makes sense to expect a decrease in digestibility of the fibrous fractions, DDM, and DOM as a result of the inclusion of CT [46] in the ration.

In this study, treatment $3(1.2 \%$ CT in diet) reduced DE significantly (Table 2). However, that probably did not result from CT contained in diet, because estimation of metabolizable energy (ME) also showed a reduction derived from low TDN concentration in treatment 3 . Similar reductive effects in DE have been reported elsewhere [9].

Digestibility of CP was significantly higher for treatments 2 and 3 relative to treatment 0 (Table 2). Similar results have been found for doses of $0.83 \%, 1.37 \%$, and $1.89 \%$ CT [47]. Results suggest that there were effective bonds between dietary proteins and CT in the rumen and consequently the intestinal absorption of protein was increased $[37,43]$. However, in this study the dose of $1.2 \%$ CT (treatment 3 ) did not increase digestible CP. This result for treatment 3 can be partially explained by the disproportion between the contributions of energy and protein that affects microbial fermentation in the rumen. Several studies are in agreement showing a linear digestible CP depression at increased doses of CT $[8,9,41,42]$.

Several authors have attempted to explain the reduction of digestibility by an incomplete dissociation of the CT-P complexes in the abomasum (due to $\mathrm{pH}$ conditions) reaching the intestine and not being absorbable. In this case, the synthesis of irreversible bonds between CT and dietary proteins is suggested. However, there is evidence that dietary CT-P bonds are reversible and largely dissociated in the abomasum [48]. Other authors propose that the digestibility reduction results from the ability of $\mathrm{CT}$ to form new complexes with $\mathrm{N}$ from endogenous origin within the intestine $[17,48]$. This theory has been supported by several studies involving $\mathrm{N}$ balance $[9,41,42]$. 
The hydrogen potential is a quantitative measure of acidity or alkalinity of a solution. A stable rumen $\mathrm{pH}$ is a precondition for the growth of microorganisms, the fermentation of ingested feed, and the absorption of organic acids [49]. In the present study rumen $\mathrm{pH}$ values did not vary significantly (on average $6.5 \pm 0.05$ ) among treatments. Similar results have been reported elsewhere, with average $\mathrm{pH}$ values of $6.6 \pm 0.2$ at CT concentrations of $<2 \%$ [40-42,47]. This result could be explained by the proportion of forage in the rations of the above mentioned studies, which was kept at above $>50 \%$ of DM. Forage consumption stimulates salivary excretion which in turn is an important factor in maintaining a stable rumen $\mathrm{pH}$ [49].

In this study, CT from DLL did not affect rumen fermentation with regard to total VFA concentration, molar proportions of propionate $\left(C_{3}\right)$, butyrate $\left(C_{4}\right)$, and the acetate to propionate ratio $C_{2}: C_{3}$. These results are in accordance with other studies [40-42], all of them at doses $\leq 2 \% \mathrm{CT}$. On the other hand, they differ from results showing a reduction in total VFA concentration [8], $C_{2}$ [8], $C_{4}$ [47], and $C_{2}: C_{3}$ ratio $[8,47]$. Furthermore, increments of $C_{3}$ [47] have been reported. The difference of effects on rumen fermentation might be related to the doses and ability of $\mathrm{CT}$ in forming complexes with dietary proteins, inhibition of catalytic activity of extracellular enzymes, or the reduction of bacterial populations [17]. It has also been proposed that $\mathrm{CT}$ reduces the acetic acid:propionic acid ratio which in turn reduces the amount of available hydrogen for methanogenesis [50]; however, in this study such effect was not observed.

The CP:TDN ratio of 0.19 or $190 \mathrm{~g} \mathrm{CP} \mathrm{kg}^{-1} \mathrm{TDN}$ is a reference for efficient daily weight gain $(0.84$ $\mathrm{kg}$ ) and minimal $\mathrm{CH}_{4}$ emissions for cattle during growth compared to cattle fed at lower CP:TDN values [51]. Although the concentration of nitrogen intake was similar among treatments with DLL, the CP:TDN ratio (Table 6) indicates with higher precision the differences in nitrogen intake as a result of increasing DLL in diets. Furthermore, the ratio of TDN:CP can be used to identify the balance of nutrients in the rumen. A TDN:CP ratio between 4:1 to 7:1 is considered an adequate contribution of $\mathrm{N}$ in cattle. Ratios higher than 7:1 indicate a deficiency of rumen degradable CP. On the other side, ratios that are $<4: 1$ show an excess $\mathrm{N}$ or a lack of energy relative to the amount of rumen degradable $\mathrm{CP}$ [52]. In this study, following the criterion of TDN:CP, treatments 2 and 3 suggest an excess $C P$.

Concentration of BUN correlates directly with the concentration of $\mathrm{CP}$ in the feed and the concentration of ammonia in the rumen. BUN range for cattle has been established as an indicator for desirable productive performance. It varies depending on the productive phase and the production system, in the case of growing animals, a range between 9 and $12 \mathrm{mg} \mathrm{dL}^{-1}$ has been suggested as optimal [53]. BUN concentrations outside this general range in cattle are indicative of deficiency $\left(<6 \mathrm{mg} \mathrm{dL}^{-1}\right)$ and excess of protein supply $\left(>19 \mathrm{mg} \mathrm{dL}^{-1}\right)[53,54]$. BUN determined for the treatments hereby described are within the range for growing cattle. Treatments 1 and 2 showed a higher BUN compared to treatment 0 . In accordance with these results in another study, doses of $0.83 \%$ and $1.89 \%$ CT increased BUN compared to the control treatment [47]. By contrast, a reduction of BUN at doses below 1.9\% CT has been also reported [42], which compares well with the reduction in BUN observed at the dose of $1.2 \% \mathrm{CT}$ in this trial. These findings may be associated with the capacity of CT-P complex formation which in turn depends on the source and the growth stage of the legume [41,44].

Results previously shown, indicated a reduced CP digestibility, which could be a consequence of increased complex formation between endogenous nitrogen and CT in the small intestine, which is then excreted in the feces. Thus, it seems important to explore in more detail the effects of such endogenous $\mathrm{N}$ excretion in feces. The loss of $\mathrm{N}$ in feces showed a linear positive trend, possibly correlated with $\mathrm{CT}$ concentrations in the diet. Previous studies revealed decreased CP digestibility at doses $<1.9 \%$ $\mathrm{CT}$, while $\mathrm{N}$ retention was not affected, the excretion of $\mathrm{N}$ in feces increased, whilst $\mathrm{N}$ excretion in urine was reduced $[9,41,42]$. On the other hand, the Nf:Ni ratio helps to explain effects related to the proportion of excreted Nf. In this case, treatments 2 and 3 showed increased Nf compared to the other treatments. This effect can be explained by the increase in CP and CT with high doses of DLL. This fact can be reinforced with PC:DOM ratio $>0.288$ for treatments 2 and 3 because the interval of 
0.191-0.218 of CP:DOM ratio is interpreted as the range of higher efficiency of nitrogen utilization in grazing cattle [55]. Also, CP:DOM ratios greater than 0.288 suggest a loss of N [55].

Rumen populations of microorganisms are responsible for the fermentation of feed. As a result, most of the proposed strategy to reduce enteric $\mathrm{CH}_{4}$ production is by regulating their growth, quantity, and metabolism. Rumen microbiota (protozoa, bacteria, and methanogenic archaea) quantified by means of qPCR were not affected by treatments in this study. Previous investigations had obtained the same results of quantification analysis of rumen microbial populations [41,56]. One possible explanation is that some microorganisms are adapted with protective mechanisms against $\mathrm{CT}$, such as the production of polymers for cellular protection and tannin degrading enzymes $[17,50]$.

Results obtained did not show any difference with regard to the total quantity of microbial populations. However, the results on digestibility can be a consequence of increased inhibition of bacterial enzymatic activity with increasing $\mathrm{CT}$ in the diets. Some studies that include the identification of specific genera for microbial diversity and bacterial enzymatic activity using omic tools have shown in more detail that the effect of some secondary metabolites in rumen microorganisms are still present, while the quantity of microorganisms does not seem to be affected [57-59]. Enteric $\mathrm{CH}_{4}$ mitigation is undoubtedly related to direct and indirect effects of $\mathrm{CT}$ on microbial populations. The mechanisms of action of CT shown in several experiments are as follows: antimicrobial effect on cellulolytic and proteolytic bacteria, interference with the catalytic activity of extracellular enzymes acting on fermentation of feed, reduced availability and digestibility of nutrients [17,50]. Otherwise, CT induce a defaunating effect of protozoa $[7,45,60]$. In the case of methanogenic archaea, a growth inhibiting effect has been proposed [61].

In the present study treatments 2 and $3(0.8 \%$ and $1.2 \% \mathrm{CT})$ decreased production of $\mathrm{CH}_{4} \mathrm{~g} \mathrm{~kg}^{-1}$ DM (13.5\% and $20.7 \%$ compared to treatment 0 ) (Table 6). These results are similar with what was observed at $1.37 \%$ and $1.89 \%$ CT in DLL [47], and doses of $0.9 \%$ and $1.36 \%$ CT in Acacia mearnsii [9]. Reduction of enteric $\mathrm{CH}_{4}$ with the inclusion of DLL in the diets could be explained by the lower digestibility of the crude protein and $\mathrm{OM}$ in the rumen. This effect is attributed to the ability of the CT to form complexes CT-P [9,47].

The evaluation index of strategies (chemical products, ingredients, secondary metabolites, and feed management, amongst others) proposed in various studies for the mitigation of enteric $\mathrm{CH}_{4}$ emissions is usually expressed in $\mathrm{g} \mathrm{kg}^{-1}$ DMI. However, it has been shown that the results obtained with this index differ from those defined as $\mathrm{CH}_{4}$ units per unit of product generated by cattle (milk or weight gain). The objective of the latter is to assess if the mitigation effect of $\mathrm{CH}_{4}$ compromises animal production $[62,63]$. As a consequence, more studies that include production variables are needed to discern the real potential of the strategies under investigation. In this context, the inclusion of doses of $0.9 \%$ and $1.36 \% \mathrm{CT}$ in Acacia mearnsii decreased the production of $\mathrm{CH}_{4}$ [9]. However, the adequate concentration of $\mathrm{CT}$ recommended to reduce $\mathrm{CH}_{4}(14 \%)$ without negative effects on milk production was $0.9 \%$ [9].

On the other hand, the Intergovernmental Panel on Climate Change, (IPCC) [1,4] suggest to determine emissions of $\mathrm{CH}_{4}$ in terms of unity of GEI as $\mathrm{Ym}$ or as GE loss MJ d $\mathrm{d}^{-1}$. In this study, all treatments with inclusion of DLL showed a reduction in enteric $\mathrm{CH}_{4}$ emissions when expressed both ways. For growing cattle (on pasture or in high fiber diets) Ym average value is $6.5 \%$ of GEI in Latin America [4]. The treatment without inclusion of DLL in the present study agrees with this reference.

GHG affect the atmosphere in different proportions and remains there for different lengths of time. The GWP evaluates GHG in relation to their warming potential of one unit of $\mathrm{CO}_{2}$ during the same period of time [4]. $\mathrm{CH}_{4}$ and $\mathrm{N}_{2} \mathrm{O}$ possess a GWP of 28 and 265 times higher than that of $\mathrm{CO}_{2}$, respectively [1].

The effect of $\mathrm{CT}$ in reducing enteric $\mathrm{CH}_{4}$ production has been widely documented $[8,9,17,18,64]$. However, few studies evaluate the effect of $\mathrm{CT}$ on $\mathrm{N}_{2} \mathrm{O}$ emissions. CT have been shown to increase the concentration of nitrogen in feces as a side effect $[9,41,42]$. The inclusion of the dose of $0.45 \% \mathrm{CT}$ in the diet gave a reduction in the excretion of $\mathrm{N}$ in urine without affecting digestibility of nutrients and milk 
production [42]. It has also been mentioned, that $\mathrm{N}$ excreted through feces compared to $\mathrm{N}$ from urine is less volatile and as a consequence the $\mathrm{N}$ that can be converted to $\mathrm{N}_{2} \mathrm{O}$ is reduced $[65,66]$. Otherwise, $\mathrm{N}$ in feces bound to $\mathrm{CT}$ is more resistant to degradation under soil conditions compared to organic $\mathrm{N}$ in feces [67].

In this study, estimated $\mathrm{N}_{2} \mathrm{O}$ as $\mathrm{CO}_{2}$-eq $\mathrm{d}^{-1}$ in feces was increased due to higher $\mathrm{CT}$ concentration. On the other hand, enteric $\mathrm{CH}_{4}$ as $\mathrm{CO}_{2}$-eq $\mathrm{d}^{-1}$ showed a linear trend towards a reduction at increasing DLL concentrations in the diet.

In summary, the lowest total GWP in $\mathrm{CO}_{2}$-eq $\mathrm{d}^{-1}$ of gases was established for treatment $3(1.2 \%$ $\mathrm{CT}$ in diet). Even though this treatment showed a lower digestible $\mathrm{CP}$ and DE, and also reduced BUN in contrast to the other doses of DLL. On the other hand, treatments 1 and 2 showed equal reductions in GWP compared to treatment 0 . However, treatment 2 decreased digestibility of OM and NDF while increased the digestibility of ADF and excess of $\mathrm{N}$ compared to treatment 1.

This study did not include analysis of $\mathrm{N}$ excreted in the urine as variable where the largest production of $\mathrm{N}_{2} \mathrm{O}$ may have been expected. Hence, for future studies it is important to include evaluations of $\mathrm{N}$ balance and production variables with the aim of establishing the precise doses at which CT are most effective in mitigating GHG without affecting animal production. Similar observations have been suggested when evaluating mitigation strategies for extended periods of time and interpreting the results of mitigating GHG in $\mathrm{kg}$ of product (milk and meat) obtained [68].

\section{Conclusions}

The results of this experiment demonstrate that the inclusion of DLL in the ration of growing crossbred heifers decreased the emissions of enteric $\mathrm{CH}_{4}$. Supplementation of $12 \%$ of ration DM with DLL $(0.27 \%$ CT in ration) was enough to increase the digestibility of dietary protein and organic matter while reducing $\mathrm{CH}_{4}$ production, without negative effects on the quantity of microbial populations and rumen fermentation.

Author Contributions: M.D.M.-F. carried out the animal work, all analysis, wrote the manuscript text, and prepared tables. J.A., I.C.M.-B., and M.D.M.-F. assisted with chemical composition of diets and qPCR analysis. J.C.K.-V., J.A., F.J.S.-S., J.L.R.-M., and C.F.A.-P. facilitated experimental animals and jointly supervised this work. All authors have read and agreed to the published version of the manuscript.

Funding: This study was undertaken as part of the CGIAR Research Program (CRP) on Climate Change, Agriculture, and Food Security (CCAFS), which is carried out with support from the CGIAR Trust Fund and through bilateral funding agreements. For details please visit https://ccafs.cgiar.org/donors. Additional support was provided by the Livestock CRP. We thank all donors that globally support the work of the program through their contributions to the CGIAR system. The views expressed in this document cannot be taken to reflect the official opinions of these organizations.

Acknowledgments: The corresponding author is grateful to CONACYT-México for granting a PhD scholarship at the Faculty of Veterinary Medicine and Animal Science, University of Yucatán, Mérida, México.

Conflicts of Interest: The authors declare no competing financial and non-financial interests.

\section{References}

1. Cubasch, U.; Wuebbles, D.; Chen, D.; Facchini, M.C.; Frame, D.; Mahowald, N.; Winther, J.G. Climate Change 2013: The Physical Science Basis. In Contribution of Working Group I to the Fifth Assessment Report of the Intergovernmental Panel on Climate Change; Cambridge University Press: Cambridge, UK; New York, NY, USA, 2013.

2. Gerber, P.J.; Steinfeld, H.; Henderson, B.; Mottet, A.; Opio, C.; Dijkman, J.; Falcucci, A.; Tempio, G. Tackling Climate Change Through Livestock-A Global Assessment of Emissions and Mitigation Opportunities; Food and Agriculture Organization of the United Nations (FAO): Rome, Italy, 2013.

3. Intergovermental Panel on Climate Change. Climate Change 2007. In Synthesis Report. Contribution of Working Groups I, II and III to the Fourth assessment report of the Intergovernmental Panel on Climate Change; IPCC: Geneva, Switzerland, 2007. 
4. Intergovermental Panel on Climate Change. Guidelines for National Greenhouse Gas Inventories. National Greenhouse Gas Inventories Programme; Institute for Global Environmental Strategies: Hamaya, Japan, 2006.

5. Kennedy, P.M.; Charmley, E. Methane yields from Brahman cattle fed tropical grasses and legumes. Anim. Prod. Sci. 2012, 52, 225-239. [CrossRef]

6. Ohene-Adjei, S.; Chaves, A.V.; McAllister, T.A.; Benchaar, C.; Teather, R.M.; Forster, R.J. Evidence of increased diversity of methanogenic archaea with plant extract supplementation. Microb. Ecol. 2008, 56, 234-242. [CrossRef] [PubMed]

7. Animut, G.; Puchala, R.; Goetsch, A.L.; Patra, A.K.; Sahlu, T.; Varel, V.H.; Wells, J. Methane emission by goats consuming diets with different levels of condensed tannins from lespedeza. Anim. Feed Sci. Technol. 2008, 144, 212-227. [CrossRef]

8. Beauchemin, K.A.; McGinn, S.M.; Martinez, T.F.; McAllister, T.A. Use of condensed tannin extract from quebracho trees to reduce methane emissions from cattle. J. Anim. Sci. 2007, 85, 1990-1996. [CrossRef] [PubMed]

9. Grainger, C.; Clarke, T.; Auldist, M.J.; Beauchemin, K.A.; McGinn, S.M.; Waghorn, G.C.; Eckard, R.J. Potential use of Acacia mearnsii condensed tannins to reduce methane emissions and nitrogen excretion from grazing dairy cows. J. Anim. Sci. 2009, 89, 241-251. [CrossRef]

10. Patra, A.K.; Kamra, D.N.; Bhar, R.; Kumar, R.; Agarwal, N. Plant secondary metabolites present in Terminalia chebula and Allium sativum reduce methane emission in sheep. Aust. J. Exp. Agric. 2008, 48, 1xx-lxxi. [CrossRef]

11. Romero-Pérez, A.; Okine, E.K.; Guan, L.L.; Duval, S.M.; Kindermann, M.; Beauchemin, K.A.A. Rapid Communication: Evaluation of methane inhibitor 3-nitrooxypropanol and monensin in a high-grain diet using the rumen simulation technique (Rusitec). J. Anim. Sci. 2017, 95, 4072-4077. [CrossRef]

12. Harrison, M.T.; McSweeney, C.; Tomkins, N.; Eckard, R.J. Improving greenhouse gas emissions intensities of subtropical and tropical beef farming systems using Leucaena leucocephala. Agric. Syst. 2015, 136, 138-146. [CrossRef]

13. Moreira, G.D.; Lima, P.T.; Borges, B.O.; Primavesi, O.; Longo, C.; McManus, C.; Abdalla, A.; Louvandini, H. Tropical tanniniferous legumes used as an option to mitigate sheep enteric methane emission. Trop. Anim. Health Prod. 2013, 45, 879-882. [CrossRef]

14. Makkar, H.P.S.; Blümmel, M.; Becker, K. Formation of complexes between polyvinyl pyrrolidone and polyethylene glycol with tannins and their implications in gas production and true digestibility in in vitro techniques. Brit. J. Nutr. 1995, 73, 897-913. [CrossRef]

15. Schofield, P.; Mbugua, D.M.; Pell, A.N. Analysis of condensed tannins: A review. Anim. Feed Sci. Technol. 2001, 91, 21-40. [CrossRef]

16. Harun, N.L.A.; Alimon, A.R.; Jahromi, M.F.; Samsudin, A.A. Effects of feeding goats with Leucaena leucocephala and Manihot esculenta leaves supplemented diets on rumen fermentation profiles, urinary purine derivatives and rumen microbial population. J. Appl. Anim. Res. 2017, 45, 409-416. [CrossRef]

17. McSweeney, C.S.; Palmer, B.; Bunch, R.; Krause, D.O. Effect of tropical forage Calliandra on microbial protein synthesis and ecology in the rumen. J. Appl. Microbiol. 2001, 90, 78-88. [CrossRef] [PubMed]

18. Patra, A.K.; Saxena, J.A. New perspective on the use of plant secondary metabolites to inhibit methanogenesis in the rumen. Phytochemistry 2010, 71, 1198-1222. [CrossRef] [PubMed]

19. Agricultural Food and Research Council. Energy and Protein Requirements of Ruminants. An Advisory Manual Prepared by the Agricultural Food and Research Council Technical Committee on Responses to Nutrients; CAB International: Wallingford, UK, 1993; p. 68.

20. National Research Council. Nutrient Requirements of Dairy Cattle: Seventh Revised Ed.; The National Academies Press: Washington, DC, USA, 2001; p. 4.

21. Schneider, B.H.; Flatt, W.P. The Evaluation of Feeds through Digestibility Experiments; University of Georgia Press: Athens, GA, USA, 1975; p. 168.

22. National Research Council. Nutrient Requirements of Beef Cattle, 7th Revised ed.; The National Academies Press: Washington, DC, USA, 2000; p. 3.

23. AOAC. Official Methods of Analysis of AOAC International, 18th ed.; AOAC International: Gaithersburg, MD, USA, 2005; pp. 24-44.

24. Van Soest, P.J.; Robertson, J.B.; Lewis, B.A. Methods for dietary fiber, neutral detergent fiber and non-starch polysaccharides in relation to animal nutrition. J. Dairy. Sci. 1991, 74, 3583. [CrossRef] 
25. Tilley, J.; Terry, R.A. Two-stage technique for the in vitro digestion of forage crops. J. Br. Grass. Soc. 1963, 18, 104-111. [CrossRef]

26. Makkar, H.P.S.; Blümmel, M.; Borowy, N.K.; Becker, K. Gravimetric determination of tannins and their correlations with chemical and protein precipitation methods. J. Sci. Food Agric. 1993, 61, 161-165. [CrossRef]

27. Price, L.M.; Butler, G.L. Rapid visual estimation and spectrophotometric of tannin contents of sorghum grain. J. Agric. Food Chem. 1977, 25, 1268-1273. [CrossRef]

28. Ramos-Morales, E.; Arco-Pérez, A.; Martín-García, A.I.; Yánez-Ruiz, D.R.; Frutos, P.; Hervás, G. Use of stomach tubing as an alternative to rumen cannulation to study ruminal fermentation and microbiota in sheep and goats. Anim. Feed. Sci. Technol. 2014, 198, 57-66. [CrossRef]

29. Ryan, J.P. Determination of volatile fatty acids and some related compounds in ovine rumen fluid, urine and blood plasma by gas-liquid chromatography. Anal. Biochem. 1980, 108, 374-384. [CrossRef]

30. Rojas-Herrera, R.; Narváez-Zapata, J.; Zamudio-Maya, M.; Mena-Martínez, M.E. A Simple Silica-based Method for Metagenomic DNA Extraction from Soil and Sediments. Mol. Biotechnol. 2008, 40, 13-17. [CrossRef] [PubMed]

31. Yu, Y.; Lee, C.; Kim, J.; Hwang, S. Group-specific primer and probe sets to detect methanogenic communities using quantitative real-time polymerase chain reaction. Biotechnol. Bioeng. 2005, 89, 670-679. [CrossRef] [PubMed]

32. Hook, S.E.; Northwood, K.S.; Wright, A.D.G.; McBride, B.W. Long-term monensin supplementation does not significantly affect the quantity or diversity of methanogens in the rumen of the lactating dairy cow. Appl. Environ. Microbiol. 2009, 75, 374-380. [CrossRef] [PubMed]

33. Skillman, L.C.; Toovey, A.F.; Williams, A.J.; Wright, A.D.G. Development and validation of a real time PCR method to quantify rumen protozoa and examination of variability between entodinium populations in sheep offered a hay-based diet. J. Appl. Environ. Microbiol. 2006, 72, 200-220. [CrossRef] [PubMed]

34. Lee, C.; Kim, J.; Shin, S.G.; Hwang, S. Absolute and relative qPCR quantification of plasmid copy number in Escherichia coli. J. Biotech. 2006, 29, 273-280. [CrossRef] [PubMed]

35. Canul-Solís, J.R.; Piñeiro-Vázquez, A.T.; Arceo-Castillo, J.; Alayón-Gamboa, J.A.; Ayala-Burgos, A.J.; Aguilar-Pérez, C.F.; Solorio-Sánchez, F.J.; Castelán-Ortega, O.A.; Lachica-López, M.; Quintana-Owen, P.; et al. Design and construction of low-cost respiration chambers for ruminal methane measurements in ruminants. Rev. Mex. Cienc. Pecu. 2017, 8, 185-191. [CrossRef]

36. SAS Institute. SAS/STAT Software; Version 9.00; SAS: Cary, NC, USA, 2006.

37. Mueller-Harvey, I. Unravelling the conundrum of tannins in animal nutrition and health. J. Sci. Food Agric. 2006, 86, 2010-2037. [CrossRef]

38. Soares, S.; Sousa, A.; Mateus, N.; De Freitas, V. Effect of condensed tannins addition on the astringency of red wines. Chem. Senses. 2012, 37, 191-198. [CrossRef]

39. Musco, N.; Koura, I.B.; Tudisco, R.; Awadjihè, G.; Adjolohoun, S.; Cutrignelli, M.I.; Mollica, M.P.; Houinato, M.; Infascelli, F.; Calabrò, S. Nutritional characteristics of forage grown in south of Benin. Asian-australas. J. Anim. Sci. 2016, 29, 51-61. [CrossRef]

40. Piñeiro-Vázquez, A.T.; Jiménez-Ferrer, G.; Alayon-Gamboa, J.A.; Chay-Canul, A.J.; Ayala-Burgos, A.J.; Aguilar-Pérez, C.F.; Ku-Vera, J.C. Effects of quebracho tannin extract on intake, digestibility, rumen fermentation, and methane production in crossbred heifers fed low-quality tropical grass. Trop. Anim. Health Prod. 2018, 50, 29-36. [CrossRef]

41. Theodoridoua, K.; Aufrèrea, J.; Anduezaa, D.; Pourrata, J.; Morvana, A.L.; Stringanob, E.; Mueller-Harvey, I.; Baumonta, R. Effects of condensed tannins in fresh sainfoin (Onobrychis viciifolia) on in vivo and in situ digestion in sheep. Anim. Feed Sci. Technol. 2010, 160, 23-38. [CrossRef]

42. Aguerre, M.J.; Capozzolo, M.C.; Lencioni, P.; Cabral, C.; Wattiaux, M.A. Effect of quebracho-chestnut tannin extracts at 2 dietary crude protein levels on performance, rumen fermentation and nitrogen partitioning in dairy cows. J. Dairy. Sci. 2016, 99, 4476-4486. [CrossRef] [PubMed]

43. Wanapat, M.; Cherdthong, A.; Phesatcha, K.; Kang, S. Dietary sources and their effects on animal production and environmental sustainability. Anim. Nutr. 2015, 1, 96-103. [CrossRef] [PubMed]

44. Huang, X.D.; Liang, J.B.; Tan, H.Y.; Yahya, R.; Khamseekhiew, B.; Ho, Y.W. Molecular weight and protein binding affinity of Leucaena condensed tannins and their effects on in vitro fermentation parameters. Anim. Feed Sci. Technol. 2010, 159, 81-87. [CrossRef] 
45. Makkar, H.P.S. Effects and fate of tannins in ruminant animals, adaptation to tannins, and strategies to overcome detrimental effects of feeding tannin rich feeds. Small Rumin. Res. 2003, 49, 241-256. [CrossRef]

46. Waghorn, G. Beneficial and detrimental effects of dietary condensed tannins for sustainable sheep and goat production-Progress and challenges. Anim. Feed Sci. Technol. 2008, 147, 116-139. [CrossRef]

47. Phesatcha, K.; Wanapat, M. Tropical legume supplementation influences microbial protein synthesis and rumen ecology. J. Anim. Physiol. Anim. Nutr. 2017, 101, 552-562. [CrossRef]

48. Kariuki, I.; Norton, B. The digestion of dietary protein bound by condensed tannins in the gastro-intestinal tract of sheep. Anim. Feed Sci. Technol. 2008, 142, 197-209. [CrossRef]

49. France, J.; Dijkstra, J. Volatile Fatty Acid Production. In Quantitative Aspects of Ruminant Digestion and Metabolism; Wallingford: Cambridge, MA, USA, 2005; pp. 157-175.

50. Patra, A.K.; Saxena, J. Dietary phytochemicals as rumen modifiers: A review of the effects on microbial populations. Antonie van Leeuwenhoek. 2009, 96, 363-375. [CrossRef]

51. Blair, K.E. Measured and modelled enteric methane emissions from beef cattle as affected by dietary crude protein of forage diets. Master's Thesis, The University of Manitoba, Winnipeg, MB, Canada, 2015.

52. Beck, P.; Gunter, S.; Gadberry, S. Growing Cattle on Cool-Season Annual Grasses; University of Arkansas, Cooperative Extension Service: Fayetteville, AR, USA, 2005.

53. Hammond, A.C. Use of blood urea nitrogen concentration to guide protein supplementation in cattle. In $3 r d$ Annual Florida Ruminant Nutrition Symposium; University of Florida: Gainesville, FL, USA, 1992; pp. 9-18.

54. Rhoads, M.L.; Rhoads, R.P.; Gilberto, R.O.; Toole, R.; Butler, W.R. Detrimental effects of high plasma urea nitrogen levels on viability of embryos from lactating dairy cows. Anim. Reprod. Sci. 2006, 91, 1-10. [CrossRef]

55. Detmann, E.; Valente, É.E.L.; Batista, E.D.; Huhtanen, P. An evaluation of the performance and efficiency of nitrogen utilization in cattle fed tropical grass pastures with supplementation. Livest. Sci. 2014, 162, 141-153. [CrossRef]

56. Angarita, E.; Molina, I.; Villegas, G.; Mayorga, O.; Chará, J.; Barahona, R. Quantitative analysis of rumen microbial populations by qPCR in heifers fed on Leucaena leucocephala in the Colombian Tropical Dry Forest. Acta Sci. Anim. Sci. 2015, 37, 135-142. [CrossRef]

57. Saminathana, M.; Sieo, C.C.; Gan, H.M.; Abdullah, N.; Wong, C.M.V.L.; Ho, Y.W. Effects of condensed tannin fractions of different molecular weights on population and diversity of bovine rumen methanogenic archaea in vitro, as determined by high-throughput sequencing. Anim. Feed Sci. Technol. 2016, 216, 146-160. [CrossRef]

58. Saminathan, M.; Gan, H.M.; Abdullah, N.; Wong, C.M.V.L.; Ramiah, S.K.; Tan, H.Y.; Sieo, C.C.; Ho, Y.W. Changes in rumen protozoal community by condensed tannin fractions of different molecular weights from a Leucaena leucocephala hybrid in vitro. J. Appl. Microbiol. 2017, 123, 41-53. [CrossRef] [PubMed]

59. Wallace, R.J.; Rooke, J.A.; McKain, N.; Duthie, C.A.; Hyslop, J.J.; Ross, D.W.; Waterhouse, A.; Watsonand, M.; Roehe, R. The rumen microbial metagenome associated with high methane production in cattle. BMC Genomics. 2015, 16, 839. [CrossRef]

60. Guyader, J.; Eugène, M.; Nozière, P.; Morgavi, D.P.; Doreau, M.; Martin, C. Influence of rumen protozoa on methane emissions in ruminants: A meta-analysis approach. Animal 2014, 8, 1816-1825. [CrossRef]

61. Tavendale, M.H.; Meagher, L.P.; Pacheco, D.; Walker, N.; Attwood, G.T.; Sivakumaran, S. Methane production from in vitro rumen incubations with Lotus pedunculatus and Medicago sativa, and effects of extractable condensed tannin fractions on methanogenesis. Anim. Feed Sci. Technol. 2005, 123-124, 403-419. [CrossRef]

62. Alcock, D.J.; Hegarty, R.S. Potential effects of animal management and genetic improvement on metanic methane emissions, emission intensity and productivity of sheep enterprises at Cowra, Australia. Anim. Feed. Sci. Tech. 2011, 166-167, 749-760. [CrossRef]

63. Herd, R.M.; Arthur, P.F.; Donogue, K.A.; Bird, S.H.; Bird-Garden, T.; Hegarty, R.S. Measures of methane production and their phenotypic relationships with dry matter intake, grow, and body composition trails in beef cattle. J. Anim. Sci. 2014, 92, 5267-5274. [CrossRef]

64. Carulla, J.E.; Kreuzer, M.; Machmüller, A.; Hess, H.D. Supplementation of Acacia mearnsii tannins decreases methanogenesis and urinary nitrogen in forage-fed sheep. Aust. J. Agric. Res. 2005, 56, 961-970. [CrossRef]

65. de Klein, C.A.M.; Ledgard, S.F. Nitrous oxide emissions from New Zealand agricultura-key sources and mitigation strategies. Nutr. Cycle Agroecosys. 2005, 72, 77-85. [CrossRef] 
66. Somda, Z.C.; Powell, J.M. Seasonal decomposition of sheep manure and forage leaves in soil. Community Soil Sci. Plant Anal. 1998, 29, 2961-2979. [CrossRef]

67. Maie, N.; Behrens, A.; Knicker, H.; Kögel-Knabner, I. Changes in the structure and protein binding ability of condensed tannins during decomposition of fresh needles and leaves. Soil Biol. Biochem. 2003, 35, 577-589. [CrossRef]

68. Hristov, A.N.; Oh, J.; Giallongo, F.; Frederick, T.W.; Harper, M.T.; Weeks, H.L.; Branco, A.F.; Moate, P.J.; Deighton, M.H.; Williams, S.R.O.; et al. An inhibitor persistently decreased enteric methane emission from dairy cows with no negative effect on milk production. Proc. Natl. Acad. Sci. USA 2015, 11, 10663-10668. [CrossRef] [PubMed]

(C) 2020 by the authors. Licensee MDPI, Basel, Switzerland. This article is an open access article distributed under the terms and conditions of the Creative Commons Attribution (CC BY) license (http://creativecommons.org/licenses/by/4.0/). 